observed in these reproductive cells, whereas what seem to be typical 'bouquet' and diakinesis stages, suggesting meiotic division, have been seen on the germination of the zygote. In cells of the meristoderm, of the apical meristematic tissue, and of the sterile paraphyses, a complement of eight chromosomes has been determined. In the nuclear divisions of the antheridium it has been possible to distinguish the same number of chromosomes as in the somatic cells. Only two nuclear divisions take place during development of the oogonium, and at each of these divisions eight chromosomes have been counted. Typical 'bouquet' and diakinesis stages of a reduction division have been seen on germination of the zygote. The evidence thus suggests that Halidrys siliquosa has a haploid thallus, with reduction division occurring immediately following fertilization. It seems likely that these observations will trigger-off a renewal of interest in the cytology of this important group.

\section{The New Atomic Age}

A RECENT illustrated booklet, "The New Atomic Age", published by the United Nations Department of Public Information (pp. 40. New York: United Nations; London: H.M. Stationery Office, 1956. 25 cents; 1 s. $9 d$. 1 Swiss franc), describes in nontechnical language the principles of the production of atomic energy and examines the role of nuclear energy in industry, medicine and agriculture. It emphasizes that atomic energy is nothing new, but what is new is man's harnessing of this energy. In one chapter the three categories of reactor-heterogeneous and homogeneous, fast and thermal, and breeder - are briefly described, and in the two succeeding chapters, nuclear radiations and their useful applications, and the expected economic, social and political repercussions of advances made possible by atomic energy, are outlined. The steps which have been taken towards the establishment of the future International Atomic Energy Agency, the initiative for which was first given by the President of the United States in his speech before the United Nations General Assembly on December 8, 1953, are described in the chapter on international co-operation in the atomic field, and it is shown how the various organizations and specialized agencies of the United Nations are already collecting vital information and directing their efforts towards the use of the atom for the benefit of all mankind.

\section{Isotopes of Einsteinium}

FIVE new isotopes of the element einsteinium (symbol $\mathrm{E}$, atomic number 99) with mass numbers 248-252 have been identified by members of the Radiation Laboratory and Department of Chemistry, University of California, Berkeley (Phys. Rev., 104, $1314-1319$; 1956). The isotope einsteinium-248 was identified among the products of the deuteron bom. bardment of califormium-249 with 18-22 $\mathrm{MeV}$. deuterons in a 60 -in. cyclotron. It decays principally by electron capture with a half-life of $25 \pm 5 \mathrm{~min}$. and also by the emission of $(6.87 \pm 0.02 \mathrm{MeV}$.) alpha particles. The four isotopes einsteinium-249 to einsteinium-252 were produced by bombardment of berkelium-249 with helium ions. A recoil mothod was used to separate the bombardment products from the target material, so that the target, which consisted of no more than $1.2 \times 10^{-8} \mathrm{gm}$. of berkelium, could be used many times. The nuclear properties of the isotopes, including the half-lives and types of decay, were ascertained and are listed together with many other details of the experimental arrangement and apparatus, and of the measurements taken.

\section{The Manchester Museum}

THE report of the Committee of the Manchester Museum for the year ended July 31, 1956 (pp. 24. Manchester : Manchester Museum, The University, 1956), records welcome additional annual grants from both the City Council and the University for the next five years. In view of these, considerable efforts are being made to modernize the Museum and high priority is being given to exhibition work. All depart. ments are endeavouring to increase the storage space available so that the well-organized reserve material could be readily accessible to those engaged in teaching and research. The Lancashire and Cheshire Antiquarian Fund has been used for providing two important lectures and for purchasing several interesting additions to the collections of British bronze implements as well as a sixth-century Anglo-Saxon urn. Progressive work is recorded from all departments and an impressive list of publications by members of the staff is included.

\section{The United States National Museum}

THE annual report of the United States National Museum for the year ended June 30, 1956 (pp. ix + $105+10$ plates. Washington, D.C.: Government Printing Office, 1956), states that a contract between the Government and an architect for the design of a building for the Museum of History and Technology was signed in March 1956. The schedule of require. ments for the building was based on several years study by the Smithsonian staff. It is gratifying to note that a sum of no less than 36 million dollars has been allocated for the building. The programme of modernizing the exhibition halls was continued during the year and contracts signed for a second American Indian Hall and a Health Hall. During the year the new Bird Hall and the east side of the North American Mammal Hall were completed. The curatorial part of the report records the installation of many new exhibits, and a list of publications by the staff is supplemented by a description of the investigations and researches carried out during the year.

\section{The Clean Air Act, 1956}

UNDER the title "The Clean Air Act, 1956 : a Guide for Industrialists", the Federation of British Industries has published a useful handbook (pp. vi +10 . London: Federation of British Industries, 1956. 2s.) explaining the main points of the Act and describing the provisions dealing with dark smoke, smoke from furnaces, grit and dust from furnaces, smoke control areas and smoke nuisances. Provisions dealing with scheduled processes under the Alkali Act and other special cases are summarized, as well as those relating to research and publicity and to the penalties which may be incurred under the Act.

\section{Research in Orthoptera}

THe recent increase in the number of workers engaged in locust research and much more widespread use of locusts as biological material have led to the risk of overlapping of effort and duplication of research. In the hope of reducing this risk and to facilitate communication between workers in related 